\title{
Echinophora spinosa L. (Apiaceae), a new species in the flora of Tunisia and second report from North Africa
}

\author{
Ridha El Mokni ${ }^{1,2}$ (1)
}

Key words: Echinophora spinosa L., Apiaceae, new find, North Africa, Kroumiria.

Ključne besede: Echinophora spinosa L., Apiaceae, nova najdba, Severna Afrika, Kroumiria.

\begin{abstract}
Echinophora spinosa L., a perennial member of the Apiaceae (Umbelliferae) family is known to be native to southern Europe and Algeria. More recently this taxon was collected from Tabarka (Jendouba-Kroumiria, North-Western of Tunisia) and is reported as a new species for the terrestrial flora of Tunisia. It is described and illustrated and notes on its ecology and phytosociological remarks are provided.

Izvleček

Echinophora spinosa L., trajnica iz družine Apiaceae (Umbelliferae), je domorodna vrsta južne Evrope in Alžirije. Nedavno smo to vrsto našli tudi pri mestu Tabarka (Jendouba-Kroumiria, severozahodna Tunizija). Najdba predstavlja novo vrsto v flori Tunizije. Predstavljamo njen opis ter opis ekoloških in fitocenoloških razmer.
\end{abstract}

Received: 20.7 .2019

Revision received: 19.9. 2019

Accepted: 23. 9. 2019

1 University of Jendouba, Laboratory of Silvo-Pastoral Resources, Silvo-Pastoral Institute of Tabarka, BP. 345, 8110-Tabarka, Tunisia.

2 University of Monastir, Department of Pharmaceutical Sciences "A”, Laboratory of Botany, Cryptogamy and Plant Biology, Faculty of Pharmacy of Monastir, Avenue Avicenna, 5000-Monastir, Tunisia. Email: ridha.elmokni@fphm.rnu.tn 


\section{Introduction}

In the context of our extensive field surveys and floristic investigations aiming at updating and improving the knowledge on the Tunisian vascular flora, mainly focused on the Kroumiria region (North-Western of Tunisia) (see e.g., El Mokni \& El Aouni 2012, El Mokni et al. 2014, 2015a, 2015b, El Mokni 2018, El Mokni \& Verloove 2017, 2019, El Mokni \& Domina 2019), in coastal dunes of Tabarka region in August 2018, an interesting spiny plant was found. Specimens, which are available in great abundance, resemble sea holly in their general appearance, but differ, especially in their gathered flowers in umbels. After checking the pertinent works on the Tunisian flora and checklist, and the North African flora (e.g., Pottier-Alapetite 1979, Le Floc'h et al. 2010, Dobignard \& Chatelain 2011, APD 2019) we can state that our discovery represents the first record of the genus in Tunisia and the second for North Africa.

The genus Echinophora L. (Apiaceae) in the Mediterranean area is represented by seven species (Hand 2011). In North Africa, only E. spinosa L. was reported from Algeria as a very rare taxon (Quézel \& Santa 1963, APD 2019).

A more detailed examination of collected specimens revealed it to be Echinophora spinosa L., which is a new record for the flora of Tunisia (Pottier-Alapetite 1979, Le Floc'h et al. 2010, Dobignard \& Chatelain 2011, Hand 2011, APD 2019). In this paper, the finding of the new species is reported, detailed illustrations of its components are provided, its new actual distribution area together with its syntaxonomic status are discussed.

\section{Material and methods}

The present work is based on both field surveys within Kroumiria region (periods 2015-2019), analysis of relevant literature and examination of specimens preserved at National Superior School of Agronomy of El Harrach (Algiers) available at http://gdebelair.com/herbier.html and my personal collection which is deposited in the Herbaria of the Faculty of Pharmacy of Monastir (not listed in Index Herbariorum).

The description is in part original based on direct observations of Tunisian specimens.

\section{Research area}

Kroumiria in Tunisia is defined geographically as series of mountainous chains, South South-Western - North North-Eastern, which rise to $1203 \mathrm{~m}$ at Djebel El Ghorra on the Tunisian-Algerian border. It is about $30 \mathrm{~km}$ wide, bordered on the South by the "MejardaValley", on the
West by the Algerian border and on the North and East by the Mediterranean sea, area of the extended dunes (Tabarka region) (Rouvier 1977, Talbi et al. 2008) with coordinates between $36^{\circ} 24^{\prime} 08^{\prime \prime} \mathrm{N}$ to $37^{\circ} 02^{\prime} 00^{\prime \prime} \mathrm{N}$ and $08^{\circ} 09^{\prime} 14^{\prime \prime} \mathrm{E}$ to $08^{\circ} 59^{\prime} 26^{\prime \prime} \mathrm{E}$. Geologically, the entire study area corresponds to the field of flyshs with the largest $\mathrm{Nu}$ midian unit. This unit extends from the Oligocene to the lower Miocene (Rouvier 1977). Kroumiria is bioclimatically the most rainy region of Tunisia sometimes till 2200 $\mathrm{mm}$ per year) included in the humid bioclimate with mainly temperate to hot winters, in the dunes of Tabarka.

Vegetation within Kroumiria is dominated by oak species (Quercus spp.) with sporadically conifers and deciduous trees at little extends and very diverse undergrowth (shrubs and bushes). Dunes are dominated by communities of Quercus coccifera and planted pines and eucalyptus.

\section{Results and discussion}

Echinophora spinosa L. Sp. Pl.: 239. 1753 三Selinum spinosum (L.) E. H. L. Krause J. Sturm, Deutschl. Fl. Abbild., ed. 2, 12: 81 (1904) E Echinophora maritima Gouan (cf. Hassler 2018). Described firstly from "Habitat ad litora maris praesertim mediterranei." - Generitype (designated by Hitchcock, Prop. Brit. Bot.: 138. 1929.). Lectotype: Herb. Burser XVI (2): 14 (UPS) (designated by Reduron \& Jarvis in Jarvis et al. (ed.), Regnum Veg. 127: 44 (1993)).

Description (Figure 1): Perennial plant $20-50 \mathrm{~cm}$, glaucous, glabrescent, with thick and deep roots; stem robust, furrowed, full, with many branches spread in high corymbs; leaves stiff, fleshy, oblong, bipennate, with spiny lobes, carinated below, canaliculate above; white or slightly pink, radiant, polygamous flowers, only the central is fertile in the sessile umbellula; umbels 9-12(-14) short, thick, angular, unequal, pubescent; involucre with 5-8 linear-lanceolate, spiny, keeled leaflets, almost as long as the umbel; calyx with 5 stiff, spiny teeth; petals obovate, emarginate, with curved tip; erect, elongated styles; fruit enclosed in the receptacle, oblong, shortbilled; mericarps with 5 equal sides, depressed, wavy.

Phenology: flowering and fruiting times August-October. Native habitat and distribution area: Echinophora spinosa L. is native to southern Europe (Albania, Baleares, Corse, Corfu Island, Croatia, France, Greece, Italy, Montenegro, Sardegna, Sicilia, Spain) and Algeria (Govaerts 2001, Dobignard \& Chatelain 2011, Hand 2011, KBD 2017, APD 2019).

In Tunisia, our first observation was in august 2018 along the coastal dunes of Tabarka (North-Western of Tunisia). 

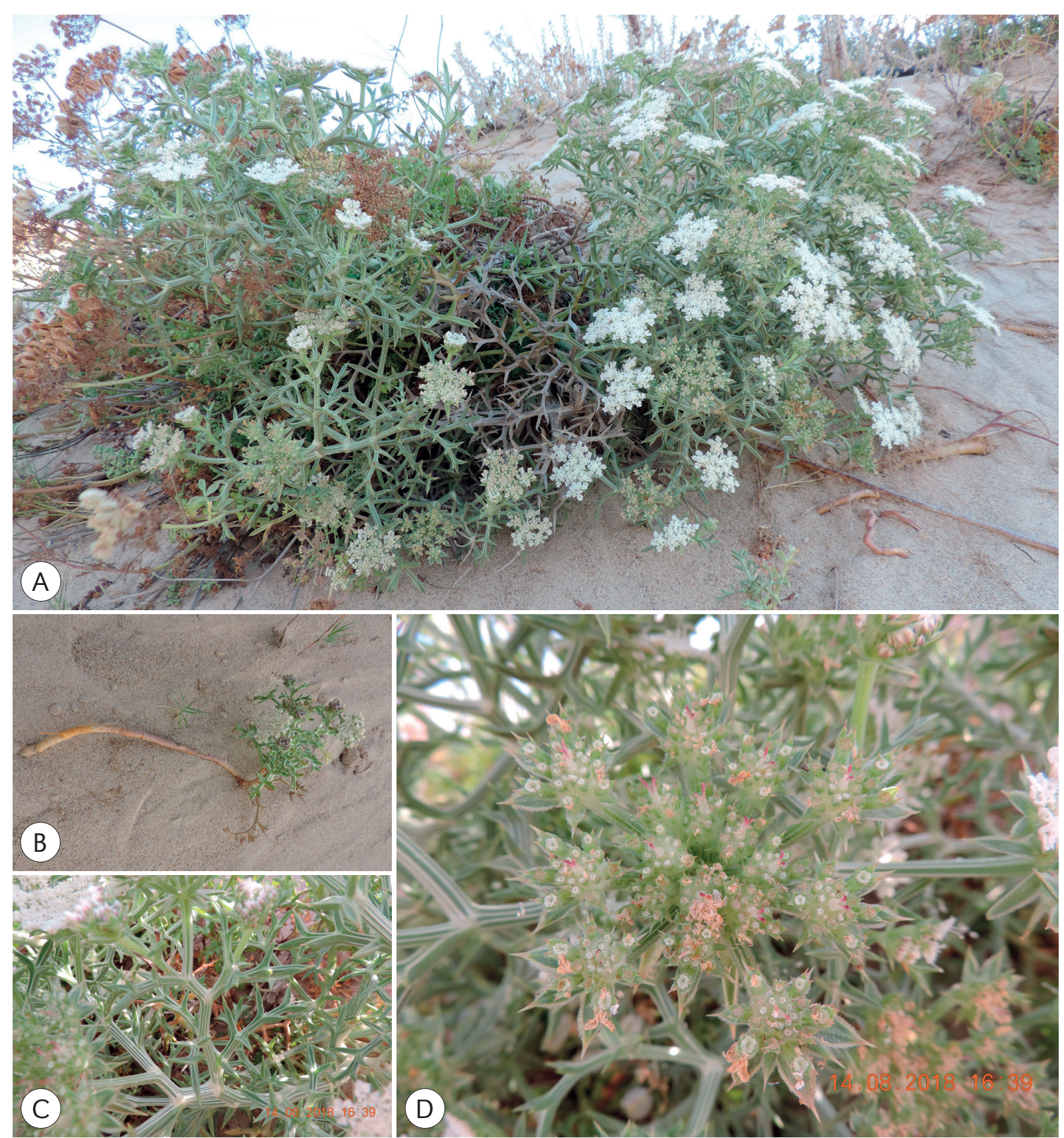

Figure 1: Habit of Echinophora spinosa L. A: Plant in its habitat; B: perennial thick and deep root; C: bipennate, spiny leaf; D: several umbellula within an umbel at the sandy low dunes of Tabarka (Kroumiria, North-Western of Tunisia) where the species was recorded for the second time to North Africa. Photos: R. El Mokni.

Slika 1: Habitus vrste Echinophora spinosa L. A: rastlina na rastišču; B: trajna in globoka korenina; C: deljeni, trnasti listi; D: več kobulčkov, združenih v kobul, na peščenih sipinah pri mestu Tabarka (Kroumiria, severozahodna Tunizija), kjer je bila vrsta v Severni Afriki zabeležena drugič. Fotografije: R. El Mokni.

Habitat and ecological notes: Echinophora spinosa L. grows in Tunisia in open sandy communities not far away the sea at low altitudes of about $2-3 \mathrm{~m}$ a.s.l. Historically, the plant was not cited before nevertheless it may be present but not distinguished or misidentified.
Notes on vegetation and syntaxonomy: Echinophora spinosa L. was found in open and herbaceous communities characterized mainly by native medium-sized species, some of them have high national/regional ecological value (endemics and subendemics) (see Table 1). 
Table 1: Plants identified within the habitat of Echinophora spinosa L. (Apiaceae) in Tabarka (Kroumiria, North-Western of Tunisia). The actual status (3rd column) is due to our floristic monitoring within Kroumiria region and mainly the coastal area of Tabarka, since 2001. Abbreviations. 2nd column: $\mathrm{C}=$ chamaephyte, $\mathrm{G}=$ geophyte, $\mathrm{H}=$ hemicryptophyte, $\mathrm{Ph}=$ phanerophyte, $\mathrm{T}=$ therophyte. Simple asterisks $\left(^{*}\right)$ in the 1 st column indicate species with high national ecological value within the region of the new record. Double asterisks $\left.{ }^{* *}\right)$ in the 1 st column indicate species with high Mediterranean ecological value (Tuniso-Algerian endemics in Domina \& El Mokni 2019).

Tabela 1: Vrste najdene na rastišču vrste Echinophora spinosa L. (Apiaceae) pri mestu Tabarka (Kroumiria, severozahodna Tunizija). Pogostnost vrste je predstavljena v tretjem stolpcu na podlagi florističnega monitoringa območja Kroumiria in predvsem obalnega predela pri mestu Tabarka od leta 2001. Okrajšave: drugi stolpec: $\mathrm{C}=$ hamefit, $\mathrm{G}=$ geofit, $\mathrm{H}=$ hemikriptofit, $\mathrm{Ph}=$ fanerofit, $\mathrm{T}=$ terofit. Zvezdica $\left(^{*}\right)$ v prvem stolpcu označuje vrste z veliko ekološko vrednostjo na nacionalnem nivoju. Dve zvezdici $(* *)$ pa označujeta vrste z veliko ekološko vrednostjo v Sredozemlju (endemiti Tunizije in Alžirije po Domina \& El Mokni 2019).

\begin{tabular}{|c|c|c|}
\hline Plants name & Life form & Status \\
\hline Achillea maritima (L.) Ehrend. \& Y. P. Guo & $\mathrm{C}$ & Quite abundant \\
\hline Ammophila arenaria subsp. arundinacea (Host) H. Lindb. & G & Quite abundant \\
\hline Anthemis maritima L. subsp. maritima & $\mathrm{C}$ & Quite abundant \\
\hline Calendula suffruticosa Vahl & $\mathrm{H}$ & Abundant \\
\hline Calystegia soldanella (L.) Roem. \& Schult. & $\mathrm{H}$ & Quite abundant \\
\hline Centaurea sphaerocephala $\mathrm{L}$. & $\mathrm{C}$ & Quite abundant \\
\hline Elytrigia juncea (L.) Nevski & G & Quite abundant \\
\hline Eryngium maritimum $\mathrm{L}$. & $\mathrm{H}$ & Quite abundant \\
\hline * Euphorbia biumbellata Poir. & $\mathrm{H}$ & Very scarce, restricted to Tabarka (Kroumiria) in Tunisia \\
\hline Euphorbia paralias L. & $\mathrm{C}$ & Quite abundant \\
\hline Euphorbia peplis L. & $\mathrm{T}$ & Scarce, very located \\
\hline ** Linaria pinnifolia (Poir.) Maire & $\mathrm{H}$ & Scarce, very located with vulnerable habitat \\
\hline Lomelosia rutifolia (Vahl) Avino \& P. Caputo & $\mathrm{H}$ & Quite abundant \\
\hline Lotus cytisoides $\mathrm{L}$. & $\mathrm{H}$ & Quite abundant \\
\hline * Orobanche litorea Guss. & $\mathrm{T}$ & $\begin{array}{l}\text { Scarce, restricted to Tunisia in North Africa and to Tabarka } \\
\text { (Kroumiria) in Tunisia }\end{array}$ \\
\hline Pancratium maritimum $\mathrm{L}$. & G & Quite abundant \\
\hline Polygonum maritimum $\mathrm{L}$. & $\mathrm{H}$ & Quite abundant \\
\hline Rouya polygama (Desf.) Coincy & $\mathrm{C}$ & Scarce, very vulnerable habitat \\
\hline ** Rumex aristidis Coss. & $\mathrm{C}$ & Very scarce, very located with vulnerable habitat \\
\hline Salsola tragus $\mathrm{L}$. & $\mathrm{T}$ & Quite abundant \\
\hline Sporobolus pungens (Schreb.) Kunth & G & Quite abundant, first report from Kroumiria in Tunisia \\
\hline Tamarix africana Poir. & $\mathrm{Ph}$ & Some individuals \\
\hline
\end{tabular}

These pioneer perennial plant communities develop typical floral carpet from spring to autumn in coastal mobile embryonic sandy dunes. From the phytosociological point of view, plant communities rich with several chamaephytes (Achillea maritima, Anthemis maritima subsp. maritima, Centaurea sphaerocephala, Euphorbia paralias, Rouya polygama, Rumex aristidis) including Echinophora spinosa L. as one of the Ammophiletea elements and as an accompanying species could belong mainly to Crucianellion maritimae Rivas Goday et Rivas-Martínez 1958 (Marcenò et al. 2018). Throughout the North African coastline, such syntaxon identified mainly due to its similar exceptional vegetation (Ammophila arenaria subsp. arundinacea, Calystegia soldanella, Elytrigia juncea, Eryngium maritimum, Euphorbia paralias, Pancratium maritimum, Polygonum maritimum, Sporobolus pungens) extends within the sandy coast in the East of Jijel (Algeria), where it is formed by an "exclave" of dune wherein Echinophora spinosa and Achillea maritima are the characteristics species (see Thomas 1968, Géhu et al. 1992, Khennouf et al. 2018). According to this available literature and on the basis of our recent observations and our new reports, the actual status of this syntaxon shows an extended area in North African coastline (from Jijel to Annaba in Algeria then to Tabarka dunes in Tunisia) and this is its first report from Tunisia in the south of the Mediterranean basin. This finding contributes well to the knowledge of the chorology and ecology of Echinophora spinosa within the Mediterranean area. It emphasizes also the great botanical value attributed to this whole area of the North African coast as a regional "hot-spot" of biodiversity, named "Kabylia-Numidia-Kroumiria" (Véla \& Benhouhou 2007). Thus, more recently coastal 
dunes of Jijel (Algeria) are proposed as a new Important Plant Area (Khennouf et al. 2018). For Tunisia, this discovery increases the Tunisian floristic diversity with two taxa (a genus and a species within the Apiaceae family) and a dunal syntaxon which is still very localized within Kroumiria region in the North-Western.

Taxonomic notes: Compared to European description (see e.g. Jeanmonod \& Gamisans 2007, Tison et al. 2014), and herbaria vouchers in gdb herbarium (Algeria, North Africa) available at http://gdebelair.com/tax/ famiumbe.html\#Echinophora, habit of collected samples in Tunisia (North Africa, South Mediterranean Basin) appear to be similar to those of European countries (North Mediterranean basin) concerning the leaves shape and the colour of flowers (white or pink). However, umbels despite their habitual morphology, show 9-12(-14) short and unequal rays (vs 5-8(-20) in European descriptions) (see e.g., Coste 1990, Jeanmonod \& Gamisans 2007, Tison et al. 2014).

Specimens examined (new records to the flora of Tunisia): Tabarka (Kroumiria, North-Western of Tunisia), on sandy coastal dunes, inflorescence white to pink, 36 $57^{\prime} 15^{\prime \prime} \mathrm{N}$, 8'47'14"E, 2-3 m above sea level (Figure 2).

Specimina visa: TUNISIA. Tabarka: North-eastern of Kroumiria, 36 $57^{\prime} 15^{\prime \prime} \mathrm{N}, 08^{\circ} 47^{\prime} 14^{\prime \prime E}$ sandy communities, not far away from road margins, and typically on and between low sandy hills at 2-3 m a.s.l., 14 August 2018, El Mokni s.n. (Herb. El Mokni!), El Mokni s.n. (Herb. Univ. Monastir).

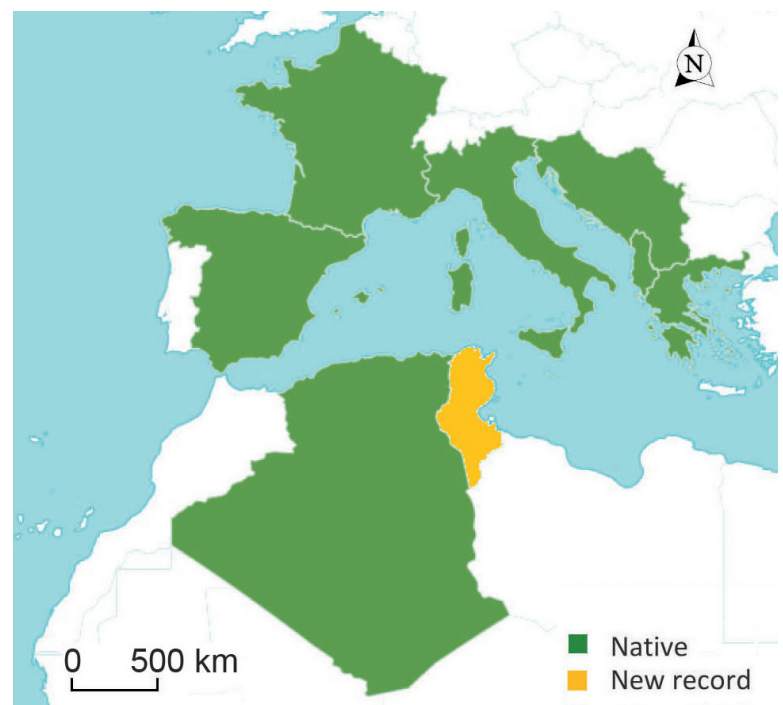

Figure 2: Actual distribution area of Echinophora spinosa L. with new localities for Tunisia, North Africa. (Source: http://powo.science.kew. org/taxon/urn:lsid:ipni.org:names:841514-1, slightly modified by the Author!).

Slika 2: Območje razširjenosti vrste Echinophora spinosa L. z novimi lokalitetami v Tuniziji (Severna Afrika).

\section{Acknowledgments}

My thanks go to all colleagues and friends of RCDA of Jendouba and Aïn Draham (Kroumiria) for their support and their help during my field studies.

Ridha El Mokni (D, https://orcid.org/0000-0003-3849-1039

\section{References}

APD. 2019: African Plant Database (version 3.4.0). Echinophora spinosa L. - Conservatoire et Jardin botaniques; South African National Biodiversity Institute, Pretoria Genève, viewed 20 July 2019, from http://www.villege.ch/musinfo/bd/cjb/africa/

Coste, H. 1990 : Flore descriptive et illustrée de la France, de la Corse et des contrées limitrophes, Vol. 2, p. 224. Librairie Scientifique et technique Albert Blanchard, Paris.

Dobignard, A. and Chatelain, C. 2011 : Index synonymique de la flore d'Afrique du nord, Vol. 2, p. 89. Éditions du conservatoire et jardin botaniques, Genève.

Domina, G. \& El Mokni, R. 2019: An inventory of the names of vascular plants endemic to $C$ Mediterranean and described from Tunisia. Phytotaxa 409 (3): 105-128.

El Mokni, R. 2018: Serapias $\times$ debelairii, a new natural hybrid from Tunisia within a sympatric population of $S$. stenopetala and $S$. parviflora. Journal of European Orchids 50 (1): 67-80.

El Mokni, R. \& Domina, G. 2019: Taxonomic and distributive notes on Serapias lingua subsp. tunetana (Orchidaceae), a rare endemic to Tunisia. Collect. Bot. 38: e005. https://doi.org/10.3989/ collectbot.2019.v38.005

El Mokni, R. \& El Aouni, M. H. 2012: Zantedeschia aethiopica (Araceae) a new species naturalized in the Northwest of Tunisia. Flora Mediterranea 22: 191-196.

El Mokni, R., Domina, G., Sebei, H. \& El Aouni, M. H. 2014: Hyacinthoides kroumiriensis sp. nov. (Hyacinthaceae): a new species from North West of Tunisia. International Journal of Advanced Research 2(9): 640-644

El Mokni, R., Sebei, H. \& El Aouni, M.H. 2015a: Rediscovery of a rare North African endemic Odontites (Orobanchaceae): first record and variability from Tunisia. International Journal of Advanced Research 3 (2): 376-382.

El Mokni, R., Domina, G., Sebei, H. \& El Aouni, M. H. 2015b: Taxonomic notes and distribution of taxa of Orobanche gr. minor (Orobanchaceae) from Tunisia. Acta Botanica Gallica 162 (1): 5-10.

El Mokni, R. \& Verloove, F. 2017: Ehrharta calycina Sm.- Pp. 299 In: Raab-Straube E. von \& Raus Th. (ed.), Euro+Med-Checklist Notulae, 8 [Notulae ad floram euro-mediterraneam pertinentes No. 37]. Willdenowia 47: 293 - 309.

El Mokni, R. \& Verloove, F. 2019: New records, distribution and taxonomic notes for non-native vascular flora of Tunisia - I. Poaceae. Flora Mediterranea 29: 45-53.

Géhu, J.M., Kaabèche, M. \& Gharzouli, R. 1992 : Observations phytosociologiques sur le littoral Kabyle de Bejaia à Jijel. Doc. Phytosoc., N.S. 14, pp. 305-322. 
Govaerts, R. 2001: World Checklist of Seed Plants Database in access E-F: 1-50919.

Hand, R. 2011: Apiaceae. - In: Euro+Med Plantbase - the information resource for Euro-Mediterranean plant diversity, viewed 29 August, from 2018http://ww2.bgbm.org/EuroPlusMed/PTaxonDetail.asp?Na meId $=106910 \&$ PTRefFk $=7500000$

Hassler, M. 2018: World Plants: Synonymic Checklists of the Vascular Plants of the World (version Apr 2018). In: Roskov, Y., Orrell, T., Nicolson, D., Bailly, N., Kirk, P.M., Bourgoin, T., DeWalt, R.E., Decock, W., De Wever, A., Nieukerken, E. van, Zarucchi, J. \& Penev L. (eds.) 2018: Species 2000 \& ITIS Catalogue of Life, 31st July 2018. Digital resource at www.catalogueoflife.org/col. Species 2000: ISSN 2405-8858. Naturalis, Leiden, the Netherlands.

Jeanmonod, D. \& Gamisans, J. 2007: Echinophora spinosa L. In Flora Corsica, pp. $701 \&$ 716. Edisud, Aix-en Provence, 1-922 + I-CXXXIV.

KBD. 2017: Kew Backbone Distributions. - The International Plant Names Index and World Checklist of Selected Plant Families 2018, from http://www.ipni.org and http://apps.kew.org/wcsp/

Khennouf, H., Cheffour, A., Corcket, E., Alard, D. \& Véla, E. 2018 : La végétation dunaire du littoral de Jijel (Algérie): proposition d'une nouvelle Zone Importante pour les Plantes. Revue Ecologie (Terre Vie) $73(3)$ : 344-361.

Le Floc'h, E., Boulos, L. \& Véla, E. 2010: Catalogue synonymique commenté de la flore de Tunisie. Banque Nationale de Gènes de la Tunisie, Tunis. 500 p.

Marcenò, C., Guarino, R., Loidi, J., Herrera, M., Isermann, M., Knollová, I., Tichý, L., Tzonev, R. T., Acosta, A. T. R., Fitz Patrick, Ú., Iakushenko, D., Janssen, J. A. M., Jiménez Alfaro, B., Kącki, Z.,
Keizer Sedláková, I., Kolomiychuk, V., Rodwell, J. S., Schaminée, J. H. J., Silc, U. \& Chytrý, M. 2018: Classification of European and Mediterranean coastal dune vegetation. Applied Vegetation Science 21: 533-559.

Pottier-Alapetite, G. 1979: Flore de la Tunisie. AngiospermesDicotylédones. Apétales-Dialypétales. Imprimerie Officielle, Tunis. $651 \mathrm{p}$.

Quézel, P. \& Santa, S. 1963 : Nouvelle flore de l'Algérie et des régions désertiques méridionales, Vol. 2, 655-656, CNRS, Paris. 600 p.

Rouvier, H. 1977: Géologie de l'Extrême Nord-tunisien: Tectonique et paléogéographies superposées à l'extrémité orientale de la chaine nordmaghrébine. Thèse d'Etat, Paris, pp 703.

Talbi, F., Melki, F., Ben Ismail-Lattrache, K., Alouani, R. \& Tlig, S. 2008: Le Numidien de la Tunisie septentrionale: données stratigraphiques et interprétation géodynamique. Estudios Geologicos 64: $31-44$.

Tison, J.M., Jauzein, Ph. \& Michaud, H. 2014 : Echinophora spinosa L. in Flore de la France méditerranéenne continentale : 1814, 2080 pages ISBN 978-2909717906 -Naturalia Publications.

Thomas, J. P. 1968 : Écologie et dynamique de la végétation de la dune littorale dans la région de Djidjelli. Bulletin de la Société d'histoire naturelle d'Afrique du Nord 59: 37-58.

Véla, E. \& Benhouhou, S. 2007: Évaluation d'un nouveau point chaud de biodiversité végétale dans le Bassin méditerranéen (Afrique du Nord). Comptes Rendus Biologies 330: 589-605. 